Kristina Stoeckl, Dmitry Uzlaner (Eds.):

Postsecular Conflicts

(C) 2020 innsbruck university press

ISBN 978-3-903187-99-3, DOI 10.15203/3187-99-3

\title{
Andrey Shishkov \\ Two Understandings of Tradition in Russian Orthodox Theology
}

In order to understand the issue of traditional values in Christian communities such as Russian Orthodoxy, one should first consider the theological understanding of the concept of "Tradition." I will examine this question primarily from the perspective of Russian Orthodox theology.

In Russian Orthodoxy, ecclesiastical Tradition (Traditsiia) is also called Predanie. Etymologically, the word predanie indicates the transmission (peredacha) of a thing or idea. There is no substantive difference in Orthodoxy between the meanings of traditsiia and predanie. The Russian Orthodox Church employs these terms synonymously.

When discussing the ecclesiastical understanding of Tradition, one should distinguish what could be called "Living Tradition" from various conceptions of tradition that are constructs of theological thought. "Living Tradition" is a non-reflexive narrative of an uninterrupted transmission of church experience and practices. The religious consciousness absorbed in "Living Tradition" does not give a second thought to the origins of this tradition. One could imagine "Living Tradition" in the form of a chain. As a rule, the bearer of "Living Tradition" does not see the beginning of this chain or even the places where its links are joined, but has a sense of communion in the chain. From this perspective, people generally consider as traditional the experience of the immediately preceding historical period and not the earlier periods of church history, because the comprehension of the earlier periods requires reflection and the con- 
structed work of the imagination. Thus, in modern Russian Orthodoxy, people consider many practices traditional that only relate to the recent past (say, the 1970s to 1990s) and that were considered new and occasionally even avant-garde when they first appeared (for example, frequently partaking of the Eucharist at a church service ${ }^{1}$ ). This "Living Tradition" could also be called "Fluid Tradition," since it is constantly changing, but its bearers, being immersed within the flow, do not sense the changes or discontinuities.

In Orthodoxy, the conceptualization of Tradition is a reaction to the emergence of historical criticism and historicism. In antiquity and in the medieval period, theologians worked with all available sources without distinguishing any historical stages of development. Of course, Holy Scripture has always had a special status, but the works of the Church Fathers were considered as if they were all "contemporaries." The well-known formula of St. Vincent of Lérins, who defines the catholicity of the church, comes to mind: Quod ubique, quod semper, quod ab omnibus creditum est (that faith that has been believed everywhere, always, and by all). That formula contains no historical time. The Fathers of various periods of church history seem to be on equal footing.

With the emergence of a historical consciousness in the modern era, historical criticism, which subjected the medieval conception of Tradition to deconstruction, gained momentum. Placing creedal and theological sources into their historical context allowed for the exposure of discontinuities and contradictions in the course of the historical development of ecclesiastical thought, which brought into question the very notion of catholicity. Under the weight of historical criticism, "that which has been believed everywhere, always, and by all" was stripped of integrity, which until then had been an essential attribute of catholicity.

It was in the context of modernism that various conceptions of tradition, which represented various methods for unifying the historical with the universal (catholic), began to emerge. A search for the "living and mysterious thread binding the whole historical fullness of Church

\footnotetext{
1 Today in the Russian Church, it has become the norm to partake of the Eucharist once or twice a month, while in the imperial period the usual practice was to have communion several times per year (usually at the end of each of the four fasts).
} 
life into one catholic whole" ${ }^{2}$ became the task of theologians. According to Florovsky, Holy Tradition is "a concrete expression of the Church's catholic self-consciousness," and in a similar vein, he wrote, "The Christian Faith is essentially historical and historically concrete." ${ }^{3}$

Jaroslav Pelikan, an American theologian and church historian who converted late in life from Protestantism to Orthodoxy, wrote,

"Tradition without history has homogenized all the stages of development into one statically defined truth; history without tradition has produced a historicism that relativized the development of Christian doctrine in such a way as to make the distinction between authentic growth and cancerous aberration seem completely arbitrary." ${ }^{4}$

Attempts to conceptualize Tradition can be divided into two basic approaches that I will call liberal and conservative. The liberalism and conservatism of the two approaches should be understood relatively; they are liberal or conservative only in relation to each other. Similar designations are in no way connected with political liberalism or political conservatism. Many authors who have worked within the liberal paradigm of Tradition have been rather conservative politically and culturally. Proponents of both approaches agree with one another in their view that one can only discuss Holy Tradition in the context of the life of the Church. Tradition is maintained in the Church by the Holy Spirit and is actualized by each member while experiencing the life of Christ. The two approaches differ in their definition of authentic Tradition, their method for working with Tradition, and their stated criteria for belonging to that Tradition.

The liberal conception of Tradition distinguishes the unchanging substantive core that expresses the true essence of the Christian faith

$2 \quad$ George Florovsky, "The Catholicity of the Church," in The Collected Works of George Florovsky, Vol. 1, ed. Richard S. Haugh (Vaduz: Büchervertriebsanstalt, 1987), 45.

3 Georgii Florovskii, “Bogoslovskie otryvki," Put' 31 (1931): 23; Florovskii, "Dom Otchii," Put' 7 (1927): 65.

4 Jaroslav Pelikan, The Emergence of the Catholic Tradition (100-600) (Chicago: University of Chicago Press, 1971), 9. 
from the temporary strata that are determined by historical context and that frequently overshadow or obscure this core. Proponents of the liberal paradigm consider this unchanging core to be the true Church Tradition to which it is imperative to return. The liberal approach proposes a free, critical rethinking of Church Tradition by (1) separating out and describing the core of the Christian faith, (2) purifying it from elements that obscure it, and (3) returning to the authentic foundation of the faith through the actualization of the unchanging core in modern times. Here, the instrument for the construction of Tradition is theological reason, which distinguishes the unchanging core of the faith, compares it to various elements of Church Tradition, and from this perspective considers the current state of the church. Significantly, the liberal approach to Tradition requires the freedom to theologize while taking into account the results of historical criticism.

As Russian theologian and social thinker George Fedotov writes:

"The Church's Holy Tradition is included within the common stream of historical tradition, which is ever complex, ever nebulous, and humanly interwoven in verity and falsity. Just as sin resides within human righteousness (holiness), so falsity resides within human tradition - and even in ecclesiastical tradition. The task of moral askesis consists in the pruning of sin and in the process of a person's sanctification. The task of theology consists in the release of the pure first principles of Holy Tradition from under the historical dross that has built up in time alongside religious gains." 5

Examples of the liberal approach to Tradition are theological projects like the Eucharistic ecclesiology of Fr. Nicholas Afanasiev and the liturgical theology of Fr. Alexander Schmemann. In each case, the aforementioned theologians make an attempt to ascertain the core of the Christian faith and to separate it from the historically conditioned strata, which they characterize as a distortion of Tradition. For example, Schmemann examines

Georgii Fedotov, “Pravoslavie i istoricheskaia Kritika,” Put’ 33 (1932): 4. 
the Divine Service as the source of theological thought. Yet, with this in mind, he states that it is necessary to return to the authentic (traditional) understanding of the Liturgy as an eschatological event. He writes,

"The Divine Liturgy should once more be interpreted as the leitourgia of the Church, and this is the theologian's task. But in order to resolve this task, we need to discover the true Liturgical Tradition again, and this is the liturgist's task. If the work of the theologian is to purify the Divine Liturgy, the work of the Divine Liturgy is to return to theology that eschatological fullness, which only the Divine Liturgy can 'actualize.”6

Here, we see the merging of the work of the theologian and the historian (the liturgist).

The conservative approach to Tradition consists of the adoption of the accumulated church heritage. From this point of view, Tradition itself can be depicted as a cloud (or "cloud storage"), in which private theological opinions, practices, and traditions (with a little " $\mathrm{t}$ ") are located alongside the foundational truths of the faith. The conservative conception of Tradition does not assume the existence of "an external criterion" that defines affiliation with Holy Tradition. This criterion is a personal mystical-religious experience in which one meditates upon the aspects of Tradition "through the feat of prayer, through the spiritual development of the believing personality, [and] through living communion with the eternal experience of the Church."7 Florovsky further writes, "The identity of experience is loyalty to Tradition." ${ }^{8}$ In other words, the comprehension of ecclesiastical Tradition occurs not on the basis of an analysis of Tradition and the subsequent synthesis of a theological position, but through the reinforcement of an experience that is considered similar to that of the Holy Fathers.

6 Aleksandr Schmemann, "Bogoslovie i liturgicheskoe predanie," in Sobranie statei, 1947-1983 (Moscow: Russkii Put', 2009), 230.

7 Florovskii, “Dom Otchii,” 82.

8 Florovsky, "The Catholicity of the Church," 49. 
If in the liberal approach, the basic instrument of work with Tradition is theological reason, in the conservative approach it is mystical-religious intuition. This intuition allows one to understand whether any particular theological opinion relates to Tradition or not. In such an approach, theology's task is preservation. Theology goes beyond the cloud's boundaries and works to excise heterodox elements if they suddenly float to the surface. In light of such an orientation, "preservation theology" is preoccupied more with the search for and exposure of heresy than with free theologizing and the synthesizing of theological conceptions.

Florovsky writes,

"Theologizing in its roots should be intuitive, defined as the experience of faith [and] vision, and not as a self-satisfying dialectic movement of inert abstract concepts. For in general, dogmas of faith are the truths of experience, the truths of life, and they can and should be revealed not through logical synthesis or analysis, but only through spiritual life, through the presence of testified dogmatic definitions of experience. At the basis of Orthodox 'theological opinions' and judgments there should lie not a [logical] conclusion but direct vision, contemplation.”9

Florovsky directly attacks the approach I called "liberal" above:

Mistaken and untrue is that theological minimalism, which wants to choose and set apart the "most important, most certain, and most binding" of all the experience and teachings of the Church. This is a false path, and a false statement of the question. Of course, not everything in the historical institutions of the Church is equally important and venerable; not everything in the empirical actions of the Church has even been sanctioned. There is much that is only historical. However, we have no outward criterion to discriminate between the two. The methods of outward historical criticism are inadequate and insufficient. 
Only from within the Church can we discern the sacred from the historical. From within we see what is catholic and belongs to all time, and what is only "theological opinion," or even a simple casual historical accident. ${ }^{10}$

An example of the conservative approach to Tradition is the theological project of the neo-patristic synthesis proposed by Georges Florovsky and developed further by Vladimir Lossky, Fr. John Meyendorff, Metropolitan Kallistos Ware, and today by Metropolitan Hilarion Alfeyev, Fr. John Behr, and others. At present, this project has become dominant in Orthodox theology.

I have to note one apparent peculiarity in Florovsky's position. In his work The Ways of Russian Theology, he subjects all Russian theological thought that emerged outside the influence of Byzantine theology to a devastating criticism. To him, the theological tradition that took shape from the seventeenth to nineteenth centuries proved to be irrelevant. He calls this "Western captivity" and "pseudomorphosis" - a distortion and perversion. According to Nikolai Berdyaev, "Florovsky [in The Ways of Russian Theology] essentially denies everyone, all Russian theology and philosophical thought, everywhere condemns Western influence." ${ }^{11}$ How does such a position correspond with the conservative approach to Tradition? Since one's affiliation with Tradition is determined by a religious feeling, Florovsky feels that Russian theology of the seventeenth to nineteenth centuries does not reflect the Tradition of the Church:

"The crisis of Russian Byzantinism in the sixteenth century was also a departure of Russian thought from the patristic tradition. [...] In theology, the patristic style and method were lost. [...] It is not enough to be acquainted with the texts and to know how to draw quotes and arguments from them. One should possess the theology of the Fathers from within. Intuition is perhaps more

10 Florovsky, "The Catholicity of the Church," 50.

11 Nikolai Berdiaev, “Ortodoksiia i chelovechnost', Put' 53 (1937): 61-62. 
important for this than erudition, for intuition alone revives their writings and makes them a witness." ${ }^{12}$

Florovsky excludes Russian theological thought from ecclesiastical Tradition like an editor cuts a film. Pseudomorphosis cannot be part of the Holy Tradition, which means that it should be deleted, as should other heresies and distortions. "Preservation theology" ensures that such elements are excised. For this reason, Florovsky's position fits well within the conservative approach to Tradition. Florovsky says:

"The retrieval of patristic style is the first and main postulate of the Russian theological renaissance. I do not mean a mere 'restoration,' repetition, or going back. At any rate, 'to the Fathers' always means forward, not backward. I am talking of being faithful to the patristic spirit, not the letter.” ${ }^{13}$

Other proponents of the conservative approach to Tradition are not as radical as Florovsky. They consider both Russian imperial and Soviet works within "Tradition." The works of all theologians and ecclesiastical writers ever glorified into the Communion of Saints automatically fall within the confines of Holy Tradition. Those who hold a conservative approach to Tradition create various notions of the consensus patrum, which are called upon to remove contradictions of opinion between the Holy Fathers. In its extreme expression, the conservative approach to Tradition is returning to a medieval understanding in which history is absent.

In modern Russian Orthodoxy, the conservative paradigm of relating to Tradition dominates. The Russian Orthodox Church formulates its attitude toward the modern world within this paradigm. Yet, in my view, the problem with such an approach and the "preservation theology" associated with it consists in the way its theo-analytical toolkit is subordinate to the task of unmasking heresies. "Preservation theology" does not offer a positive program of a theological apprehension of the day-toEkzarkhata, 2006), 495-96.

lbid., 496. 
day realities of the modern world and their correlation to Church Tradition. Such a position is inherently reactionary.

And although Florovsky claimed that we should create a new theology that would apprehend the day-to-day realities of the modern world "in the spirit of the Fathers," neither he nor his successors could offer a convincing social and political theology. Today's proponents of the neo-patristic synthesis see their task entirely as the retrieval and compilation of the Fathers' opinions from the entire mass of the sacred patristic legacy in order to explain modern processes. Such an approach to theology makes it completely irrelevant to the very realities of life in which the Church exists.

For example, today's Russian Orthodoxy believes that monarchic polity better corresponds to Orthodoxy than does democracy (and this is on record, including in the church's official documents). This has taken place because the vast majority of the Church Fathers lived under monarchy, and some of them justified it from theological positions; but one can only count on one hand the number of saints who would have written in defense of democracy. Yet, the restoration of monarchy in its medieval understanding is already impossible, since it has long been impossible to deny the modernist idea of the sovereignty of the people as a source of power in the state.

The irrelevance of the conclusions of "preservation theology" leads believers to some form of alienation from ecclesiastical doctrinal authority. Believers thus search for answers to their questions "on the side," turning to secular notions and explanatory strategies. They do not understand why monarchy is good, but democracy, human rights, and capitalism are bad. Is it merely because the latter did not exist in the times of the Church Fathers? At the recent Holy and Great Council of the Orthodox Church in Crete, participants seriously discussed the question of whether it was permissible to utilize the term "human person" (prosopon) in church documents dedicated to social issues. ${ }^{14}$ One of the obvious proponents of the neo-patristic synthesis, Metropolitan Hierotheos Vlachos, explained the

"The Mission of the Orthodox Church in Today's World," Holy and Great Council of the Orthodox Church, accessed 30 August 2017, https://www.holycouncil.org/-/missionorthodox-church-todays-world?_101_INSTANCE_VAOWE2pZ4YOI_languageld=en_US. 
problem by stating that the Holy Fathers never used the term person in their writings. ${ }^{15}$

A second problem facing "preservation theology" is that one cannot even call it "theology" in the strictest sense of the word. The most essential thing - the theological element - is missing from this stance. This theology does not correspond to God, but to a sacralized historical tradition that exists "in this age" - the saeculum. In one sense, it represents a secularized form of religious thought. The example of the debates around the human person wonderfully illustrates this point. In the case of Metropolitan Hierotheos, a commitment to historical tradition has won out over a theological approach. He rejected the term "human person" not because there can be no theological content within it, but because the Greek Holy Fathers did not ever use it. As a result, the Church continues to speak with believers in a little-understood, archaic language.

The absence of a relevant contemporaneity of theology does not allow believers to occupy any kind of theological position in relation to the problems and conclusions of the modern world. Moreover, this void in the place of theology actually becomes a position. And this is a common problem for today's Orthodox socio-religious thought, from representatives of the church leadership to popular publicists.

The liberal conception of Tradition looks more optimistic in this respect. It allows one to freely theologize with a reliance upon the unchanging core of the Christian faith and offers theological solutions in the language of its time, under the condition of maintaining the crucial meanings of the Christian religion. Certainly, one should separate one's own religious thoughts here from that which could be called the cultural identity of Christianity. The latter could be deeply rooted within Tradition, but that said, it does not relate to the basic principle of the Christian faith human salvation - and may even contradict it. In the final analysis, it is the salvation of the human person for eternity, and not the defense of a cultural identity of Christianity, that should be the priority for the Christians.

See more about this discussion: Paul Ladouceur, "Human Beings or Human Persons?" Public Orthodoxy, accessed 30 August 2017, https://publicorthodoxy.org/2017/06/06/ human-beings-or-persons/. 


\section{Literature}

Berdiaev, Nikolai. “Ortodoksiia i chelovechnost”" [Orthodoxy and humaneness]. Put' 53 (1937): 53-65.

Fedotov, Georgii. "Pravoslavie i istoricheskaia kritika" [Orthodoxy and historical criticism]. Put' 33 (1932): 3-17.

Florovskii, Georgii. “Bogoslovskie otryvki” [Theological fragments]. Put’ 31 (1931): 3-29.

Florovskii, Georgii. "Dom Otchii” [The house of the Father]. Put' 7 (1927): 63-86.

Florovskii, Georgii. Puti russkogo bogosloviia [The ways of Russian theology]. Minsk: Izdatel'stvo Belorusskogo Ekzarkhata, 2006.

Florovsky, George. "The Catholicity of the Church." In The Collected Works of George Florovsky, Vol. 1, edited by Richard S. Haugh, 37-55. Vaduz: Büchervertriebsanstalt, 1987.

Holy and Great Council of the Orthodox Church. "The Mission of the Orthodox Church in Today's World." Accessed 30 August 2017. https://www.holycouncil.org/-/mission-orthodox-church-todays-world?_101_INSTANCE_ VAOWE2pZ4YOI_languageld=en_US.

Ladouceur, Paul. “Human Beings or Human Persons?” Public Orthodoxy. Accessed 30 August 2017. https:// publicorthodoxy.org/2017/06/06/human-beings-or-persons/.

Pelikan, Jaroslav. The Emergence of the Catholic Tradition (100-600). Chicago: University of Chicago Press, 1971.

Schmemann, Alexander. "Bogoslovie i liturgicheskoe predanie" [Theology and liturgical tradition"]. In Sobranie statei, 1947-1983, 224-30. Moscow: Russkii Put', 2009.

Translated by April L. French 